\title{
Effect of Parents' Characteristics and Perceptions on Basic Immunization in Children at Dr. Zainoel Abidin Banda Aceh
}

\author{
Octavina Susanti $^{1}$, T.M. Thaib ${ }^{2}$, Rusdi Andid ${ }^{3}$, Sulaiman Yusuf $^{4}$, Anidar ${ }^{5}$, Jufitriani \\ Ismy $^{6}$, Darnifayanti ${ }^{7}$ \\ 1,2,3,4,5,6,7 Department of Pediatric Health, Faculty of Medicine, Syiah Kuala University / RSU D Dr. Zainoel \\ Abidin, Banda Aceh, Indonesia \\ octaavina@gmail.com
}

\begin{abstract}
Immunization is a form of health intervention that is effective in reducing infant and under-five mortality rates. In Indonesia Aceh is the province with the lowest immunization coverage, where only $20 \%$ of Acehnese children receive complete basic immunization. Me $n g$ analysis of the influence of parents' characteristics and perceptions of primary immunization in children in the General Hospital Dr. Zainoel Abidin Banda Aceh. This type of research is descriptive analytic with approach cross sectional using a questionnaire as a research instrument to the parents of the patients in the wards and child polyclinic period from June to July 2020. A sample of 51 people with methods Consecutive sampling. Data analysis used Chi-square test and Fisher exact test. Based on the results of the analysis of the relationship between parental perceptions and completeness of basic immunization, the results were obtained ( $p>0.05)$, for the assessment of the relationship between parental characteristics in the form of age, monthly income level and number of children with completeness of basic immunization in children, the results were obtained ( $p>$ 0.05)., while the characteristics of the level of parental education with completeness of basic immunization in children obtained hacil ( $p<0.05)$. There is an influence of parental characteristics, namely the level of education with completeness of basic immunization in children, while other variables, namely parents' perceptions, parental age, monthly income and number of children in one family do not affect the completeness of basic immunization in children at Dr. Zainoel Abidin Banda Aceh.
\end{abstract}

Keywords: parental perceptions; parental characteristics; basic immunization; children

\section{Introduction}

Immunization is a form of health intervention that is considered effective in reducing infant and under-five mortality rates. Immunization can prevent various diseases such as tuberculosis, diphtheria, pertussis, tetanus, hepatitis B and other diseases known as diseases that can be prevented by immunization (PD3I). 1,2 Based on the 2018 Riskesdas shows children under 2 years with complete immunization are only $57.9 \%, 32.9 \%$ with incomplete immunization and 9\% of Indonesian children without immunization at all. In Indonesia, Aceh is the province with the lowest immunization coverage, where only $20 \%$ of Acehnese children get complete basic immunization, and the lowest type of immunization is DPT-HB-HiB of $61.3 \%$.

The role of parents in the immunization program is very important, an understanding of immunization is needed, people's behavior regarding health is very much determined by the attitudes, knowledge, beliefs, traditions, etc. of the person or community concerned (Priyoto, 2015). In addition, the attitudes and behavior of health workers towards providing health information and the availability of health service facilities also support and strengthen the formation of behavior (Priyoto, 2014).

Many factors have contributed to the low immunization coverage in Indonesia, particularly in Aceh. The issue of using a number of haram (from pork) substances is the main 
cause of resistance to immunization. The rise of anti-vaccine negative campaigns that mention the various negative effects of vaccine propagated such as autism, as well as side effects of vaccines such as fever. The decline in the level of public confidence in immunization is also related to the circulation of fake vaccines that were revealed in 2016 (Rinanda, 2017)..

Apart from the vaccine factor itself, there are other factors that influence immunization. The role of a mother in the immunization program is very important, so an understanding of immunization is needed. Likewise with the knowledge, beliefs and health behavior of parents. Lack of socialization from health workers causes the problem of low understanding, understanding and compliance of mothers in the immunization program.

Previous research by Yufika et al (2018), regarding parental doubts about vaccination: a cross-sectional study in Indonesia, conducted in Aceh and North Sumatra, stated that parents' doubts about vaccination, especially on the safety and benefits of vaccines. The mother's age, education level, the decision to give vaccines by the father are the things that influence vaccination. Research by Triana et al (2017), shows that there is a relationship between the characteristics of mothers under five and the perceptions of mothers under five to immunization, on the implementation of complete basic immunization.

Research by Azizi et al (2017), regarding parental doubts about vaccination in Malaysia states that parents' doubts about vaccination among multi-ethnic groups in Malaysia are comparable to other populations and shows mothers with first children and non-working mothers are more hesitant about vaccination. The two studies above used the Parent Attitudes about Childhood Vaccines (PACV) questionnaire developed by Opel et al., Which is widely used, and is considered the most appropriate to the culture and nature of the surrounding community. The Indonesian version of PACV was tested on 10 participants for accuracy (Opel, 2013). The purpose of this study was to identify parental perceptions and completeness of immunization in children and to analyze the effect by completing basic immunization in children.

\section{Research Methods}

The design of this research is analytic descriptive with cross sectional study. The sampling method using non-probability sampling, namely consecutive sampling, obtained 51 samples that met the inclusion criteria, namely parents who have children aged 9 months to 2 years, who are willing to participate in the study and carry immunization cards in the pediatric ward and pediatric polyclinic of the General Hospital. Dr. Zainoel Abidin Banda Aceh for the period June-July 2020 and the exclusion criteria were parents who had children with immune deficiency, extensive skin infections and immunosuppressant therapy and hemodialysis. The independent variable in this study is the completeness of immunization, while the dependent variable is the perception of parents, age, gender, education level, monthly income and number of children. Analysis of the data in this study using the Chi-square test and Fisher's exact test. 0, 05. Data processing was performed using a computer program (SPSS 22.0 for windows).

The research instrument is a tool used or used by researchers to collect the required data. The instrument or data collection tool in this study was a questionnaire to assess parental perceptions about immunization using Parent Attitudes about Childhood Vaccines (PACV) developed by Opel et al. This questionnaire was widely used, initially in the form of English questions which were translated into Indonesian by translators who experienced. The Indonesian version of PACV was tested on 10 participants for accuracy. 
The PACV questionnaire consists of 15 questions, which are divided into 3 parts (behavior, safety and efficacy, and general attitude). Questions 1 and 2 about behavior. Questions 7-10 concern safety and efficacy, questions 3-6 and 11-15 concern general attitude. The doubtful response was given a score of 2, unsure or not knowing was given a score of 1 (except for questions 1 and 2, when given a "don't know" answer indicated a poor memory of immunization doubt and was given a score of 0 . The total score was from 0 to 30 . The total PACV score was converted to a scale of 0-100, then grouped into two categories: no doubt (value <50) and doubtful (value> 50).

This study has obtained ethical eligibility from the Ethics Committee of the Faculty of Medicine, Syiah Kuala University Banda Aceh with registration number 097 / EA / FKRSUDZA / 2020, on May 26, 2020.

\section{Results and Discussion}

\subsection{Result}

This research was conducted at Dr. Zainoel Abidin Banda Aceh in the nursery room for Arafah 1 children and children's polyclinic, by giving questionnaires to parents who have children aged 9 months to 2 years in the period of June and July 2020. The number of respondents was 51 people who met the inclusion criteria. Respondent characteristic data is presented in table 1.

Table 1. Basic characteristics of respondents

\begin{tabular}{ccc}
\hline Respondent Characteristics & $\boldsymbol{n}=\mathbf{5 1}$ & $\mathbf{\%}$ \\
\hline Age Group & 11 & 21.6 \\
20-29 years & 37 & 72.5 \\
30-39 years & 3 & 5,9 \\
40-49 years & & \\
Last education & 4 & 7,8 \\
Basic level & 10 & 19.6 \\
Intermediate level & 37 & 72.5 \\
High level & & \\
Income Level & 26 & 51.0 \\
$\leq 3$ million & 25 & 49.0 \\
> 3 million & & \\
Number of children & 32 & 62.7 \\
1-2 people & 19 & 37.3 \\
\hline 3 people & &
\end{tabular}

Table 2 provides information regarding the completeness of immunization and respondents' perceptions of immunization 
Table 2. Description of completeness and respondent's perception of immunization

\begin{tabular}{lcc}
\hline Variable & $\boldsymbol{n = 5 1}$ & $\mathbf{\%}$ \\
\hline Immunization Completeness & 5 & \\
There is no & 21 & 9.8 \\
Incomplete & 25 & 41.2 \\
Complete & & 49.0 \\
Perceptions of Immunization & 35 & 68.6 \\
Doubtful & 16 & 31.4 \\
Don't Hesitate &
\end{tabular}

The relationship between parental perceptions of immunization (doubtful or undecided) with the completeness of immunization given to children (absent, incomplete or complete) was analyzed by cross tabulation analysis Chi-square or by Fisher's exact test. Chisquare analysis is used when at least $80 \%$ of cells in cross tabulation have an expectation value above 5. Whereas if there are more than $20 \%$ cells with an expectation value less than 5 , then the Fisher exact test is used. Chi-square analysis or Fisher's exact test was used to see the relationship between two variables with a nominal or ordinal data scale through a comparison of the data displayed in rows and columns. The null hypothesis $\left(\mathrm{H}_{0}\right)$ in this analysis states that the two variables analyzed are not statistically related.

Table 3. The relationship between parental perceptions and completeness of immunization

\begin{tabular}{lcccc}
\hline Immunization & \multicolumn{2}{c}{ Perceptions of Immunization } & \multirow{2}{*}{ Score } & \multirow{2}{*}{ p-value } \\
\cline { 2 - 3 } Completeness & Doubtful & Don't Hesitate & & \\
\hline There is no & $1(20,0 \%)$ & $4(80,0 \%)$ & & \\
Incomplete & $16(76,2 \%)$ & $5(23,8 \%)$ & $5,431^{*}$ & $0.070^{\text {a }}$ \\
Complete & $18(72,0 \%)$ & $7(28,0 \%)$ & & \\
\hline
\end{tabular}

Based on Table 3, it is known that of the 5 respondents who did not give immunizations to their children, $4(80 \%)$ of them actually had a perception that was not in doubt about the immunization. Furthermore, for respondents who gave incomplete immunizations to their children, more than $75 \%$ (16 people) had a doubtful perception of immunization and only $24 \%$ had no doubts about immunization. Meanwhile, for respondents who gave complete immunization, 18 out of 25 respondents $(72 \%)$ had doubtful perceptions of immunization and only $28 \%$ did not have doubts about the immunization. The Fisher exact test has a $p$-value of 0.070 or greater than the significance level used at $5 \%$. Therefore, the null hypothesis in this study cannot be rejected. In other words, there is no significant relationship between parental perceptions and the completeness of immunization given to their children.

Table 4. Relationship between parental age and completeness of immunization

\begin{tabular}{|c|c|c|c|c|c|}
\hline \multirow{2}{*}{ Age Group } & \multicolumn{3}{|c|}{ Immunization completeness } & \multirow{2}{*}{ Score } & \multirow{2}{*}{$p$-value } \\
\hline & There is no & Incomplete & Complete & & \\
\hline 20-29 years & $2(18,2 \%)$ & $5(45,5 \%)$ & $4(36,4 \%)$ & & \\
\hline 30-39 years & $2(5,4 \%)$ & $14(37,8 \%)$ & $21(56,8 \%)$ & $\begin{array}{c}6,603 \\
*\end{array}$ & $0.103^{\mathrm{a}}$ \\
\hline 40-49 years & $1(33,3 \%)$ & $2(66,7 \%)$ & $0(0,0 \%)$ & & \\
\hline
\end{tabular}


Table 4 shows that more parents aged between 20-29 years and 40 to 49 years gave incomplete immunization to their children. Meanwhile, more parents aged between 30 and 39 give complete immunizations to their children. This test has a p-value of 0.103 which is greater than 0.05 . This shows that the null hypothesis cannot be rejected. Thus, it can be concluded that there is no significant relationship between the variables of parent's age and the completeness of the immunizations they provide to their children.

Table 5. The relationship between parental education and completeness of immunization

\begin{tabular}{|c|c|c|c|c|c|}
\hline \multirow[t]{2}{*}{ Level of education } & \multicolumn{3}{|c|}{ Immunization Completeness } & \multirow{2}{*}{ Score } & \multirow{2}{*}{$p$-value } \\
\hline & There is no & Incomplete & Complete & & \\
\hline Basic level & $2(50,0 \%)$ & $2(50,0 \%)$ & $0(0,0 \%)$ & & \\
\hline Intermediate level & $1(10,0 \%)$ & $5(50,0 \%)$ & $4(40,0 \%)$ & & $0.047^{\mathrm{a}}$ \\
\hline High level & $2(5,4 \%)$ & $14(37,8 \%)$ & $21(56,8 \%)$ & & \\
\hline
\end{tabular}

Table 5 provides information that the number of parents with basic education (SD and SMP and equivalent) is evenly distributed between those who did not give immunizations and those who only gave incomplete immunizations to their children. Furthermore, parents with secondary education (SMA / SMK and equivalent) are more likely to provide incomplete immunization. Meanwhile, parents with higher education (DIII and S1) are more likely to provide complete immunization. More than $77 \%$ of the number of cells cross tabulated on. The test results show that the level of parental education is related to the completeness of the immunizations they provide to their children. This can be seen from the test $p$-value (0.047) which is smaller than the significance level set at 0.05 .

Table 6. The relationship between parental income and completeness of immunization

\begin{tabular}{lcrrrl}
\hline \multirow{2}{*}{ Income Level } & \multicolumn{3}{c}{ Immunization Completeness } & \multirow{2}{*}{ Score } & \multirow{2}{*}{$\boldsymbol{p}$-value } \\
\cline { 2 - 5 } & There is no & Incomplete & Complete & & \\
\hline$\leq 3$ million & $4(15,4 \%)$ & $12(46,2 \%)$ & $10(38,5 \%)$ & 3,044 & \multirow{2}{*}{$0.212^{\text {a }}$} \\
$>3$ million & $1(4,0 \%)$ & $9(36,0 \%)$ & $15(60,0 \%)$ & $*_{*}$ & \\
\hline
\end{tabular}

Table 6 shows that in general, parents with an income of three million or less tended to give their children incomplete immunizations. Meanwhile, parents with an income above 3 million rupiah gave more complete immunization. The test results indicate that there is no significant relationship between the level of income and the completeness of the immunizations they provide because they have a $p$-value of testing greater than 0.05 .

Table 7. The relationship between the number of children and completeness of immunization

\begin{tabular}{|c|c|c|c|c|c|}
\hline \multirow[t]{2}{*}{ Number of children } & \multicolumn{3}{|c|}{ Immunization Completeness } & \multirow{2}{*}{ Score } & \multirow{2}{*}{$p$-value } \\
\hline & There is no & Incomplete & Complete & & \\
\hline 1-2 people & $2(6,3 \%)$ & $13(40,6 \%)$ & $17(53,1 \%)$ & $474^{*}$ & 0487 \\
\hline$\geq 3$ people & $3(15,8 \%)$ & $8(42,1 \%)$ & $8(42,1 \%)$ & & 0.401 \\
\hline
\end{tabular}


Based on Table 7, it is known that parents who have 1 to 2 children are more likely to provide complete immunization to their children. Meanwhile, parents who have more than 2 children in the family tend to be the same in giving incomplete and incomplete immunizations to their children. Based on the results of the Fisher exact test, the statistical test was 1.474 with a $p$-value of 0.487. P-value that is greater than 0,05 indicates that the variable number of children in the family is not related to immunization completeness that parents give to this study.

\subsection{Discussion}

The results showed that nearly $50 \%$ of the respondents had given complete immunization to their children. Meanwhile, 21 people gave incomplete immunizations. In addition, there were 5 respondents who did not give immunizations to their children. The interesting thing is seen in the respondent's perception of immunization. A total of 35 people from the total respondents who were involved in this study had doubtful perceptions of immunization. Meanwhile, the remaining 16 people stated that they did not hesitate in giving immunizations to their children. In contrast to research by Azizi in Malaysia with the results that only $11 \%$ of respondents were doubtful about immunization. 11 From the questions given to parents doubts about immunization, especially on the safety of vaccines, including side effects. 13,14 In line with previous studies which stated that one of the reasons parents did not immunize their children was because of doubts about the safety of vaccines, vaccines were considered unsafe due to the spread of misinformation by the media, the internet and antivaccine groups. Therefore, health workers must explain in more detail the benefits and risks of immunization to eliminate parental concerns and misunderstandings.

Chi-square analysis or Fisher's exact test was used to see the relationship between two variables with a nominal or ordinal data scale through a comparison of the data displayed in rows and columns. The null hypothesis $\left(\mathrm{H}_{0}\right)$ in this analysis states that the two variables analyzed are not statistically related.

Statistical analysis in this study shows that there is no strong correlation between parental perceptions and completeness of immunization in children. A person will always interact through stimuli received from himself or the surrounding environment. The interaction process makes a person understand the perception of something that is believed to shape or determine behaviour (Sunaryo, 2004). In accordance with Theory of planned behavior which states that the perception that controls the behavior is one of the supporting factors for someone to do a behavior. Perception here is one of three things that can lead to an intention to perform a behavior.

The results were 5 respondents who did not give immunizations to their children, but 4 of them did not hesitate about immunization. Furthermore, as many as 22 respondents did not complete giving immunizations to their children, with 16 of them having doubts about immunization. Meanwhile, for respondents who gave complete immunization, out of a total of 25 people, 18 people had a doubtful perception of immunization, so it can be concluded that there was no significant relationship between parental perceptions and completeness of immunization for children. This is in line with the research of Isnayni (2016), which states that there is no significant relationship between parental perceptions and parental compliance to provide immunizations.

The results of the research on parental characteristics found that there were no specific specifications for the age of the parents with the completeness of immunization in children. In line with research conducted by Yufika (2018), age does not affect parents choosing to complete child immunizations or not. 10 Different experiences with a problem in this case about basic immunization have more influence on parental perceptions. Experience with 
health problems / diseases and decision making is influenced by the age of the individual 19 Young mothers usually have new children so they tend to pay more attention to their children, including giving basic immunizations. Meanwhile, older mothers usually have more than one child and are more busy, thus affecting the motivation of mothers to bring their children to health services to get basic immunization. Age is not always the domain that supports a person in behaving because behavior is influenced by internal and external factors (Notoatmojo, 2012).

The level of education is one of the processes for shaping behavior. Education is fundamental to prepare students through teaching and practice guidance for future roles will come. The theory that the higher the education the more knowledge is obtained. This theory is in accordance with the results of research where the level of education is related to the completeness of immunization in children. In this study, the majority of respondents' education level is higher education. The results of the demographic data questionnaire show that a certain level of education has children with complete basic immunization, so that it can be said that the level of education has an influence on the completeness of immunization in children. Manado it Bertola k back with research Sewene (2017) which states there is no relationship with the education level of parents adherence to basic immunization in children. Respondents with a low level of education who remain obedient in giving immunizations are due to health workers who always provide information about the importance of basic immunization for children. Research Riska (2015) states that there is an effect of parental education on basic immunization compliance, where parents with low levels of education tend not to comply with immunizations.

Parents who have a higher level of education are easier to accept and understand about immunization messages conveyed by health workers, both through counseling and the mass media, so that they are expected to be able to apply the information they receive and provide complete immunization to their children. Education is a process of behavior change, where the higher the education of a person, the more he will choose health service places (Munib, 2004). Several studies stated that parents who have high education have a good level of knowledge about immunization, they can access information via the internet. When negative issues about vaccines develop, parents with a higher level of education can access information through books or health workers so they can analyze the information obtained in advance (Azizi, 2017).

The relationship between parental education levels and doubts about immunization is very specific, so that health workers are expected to be more careful with the community groups how immunization information is given, and cooperation with scholars and government officials is also needed so that people can receive more information about immunization, so that they routinely provide immunizations to her child according to schedule.

The monthly family income of research respondents is mostly in the middle value. Actually, the completeness of basic immunization is not influenced by family income because the basic immunization given to babies has received subsidies from the government so that parents do not need to pay fees. In line with Isnayni's (2016) research, which states that monthly income does not influence parents to complete or not complete basic immunization for children.

The number of children was mentioned in the questionnaire to see their parents' experiences regarding basic immunization. Experience is one of the factors behind the formation of one's perception. However, in general, the results showed that parents with a large number of children did not complete immunizations for their children. So it can be 
interpreted that the number of children does not affect the parents' decision to give immunizations to children (Ajzen).

Research by K ubl i (2017), most parents did not complete basic immunization because of more negative perceptions. The negative perceptions in this case include parents feeling that their baby is in good health so that they do not need to immunize, parents also feel that it is better to give medicine when a child is sick than to prevent it with basic immunization. Most parents also follow the advice of neighbors, so that misinformation also affects parents' decision to complete basic immunization for children, and is a barrier to obtaining broader immunization coverage (Kubli, 2017).

Our study has several limitations, namely that it does not analyze the reasons from the religious aspect of immunization, although in some studies it is one of the obstacles in giving immunization. In this study, the number of samples was only 51 people located in Dr. General Hospital. Zainoel Abidin Banda Aceh, so that more research samples from different locations are needed to be able to analyze the effect of parental characteristics and perceptions on immunization.

\section{Conclusion}

There is no influence of perception, age, income level of parents and number of children in one family with the completeness of immunization for children. The level of parental education affects the completeness of immunization in children.

\section{References}

Ranuh G. Pedoman Imunisasi di Indonesia. Satgas imunisasi IDAI. Edisi 6; 2017.h 271-81.

Tim IDAI. Imunisasi difteria, pertusis dan tetanus. Pedoman imunisasi di Indonesia. Jakarta: Sagung Seto; 2017. h 12-9

RI K. Hasil Utama Riskesdas 2018. Kementerian Kesehatan Republik Indonesia; 2018

Priyoto. Perubahan dalam prilaku kesehatan. Graha Ilmu. Yogyakarta; 2015. h 18-20

Priyoto. Teori sikap dan prilaku dalam kesehatan. Nuha Medika. Edisi 1. Yogyakarta. 2014; h 25-6

Rinanda T. Difteri, Imunisasi dan kekebalan komunitas; 2017 [diunduh 6 Mai 2020]. Tersedia pada www.rp2u.unsyiah.ac.id

Rakhmat J. Psikologi komunikasi. Psikologi Komunikasi. Bandung. PT.Remaja Rosdakarya; 2000. h80-91

Sunaryo. Psikologi untuk keperawatan. Jakarta. EGC; 2004. h109-117

Yufika A, Wagner AL, Nawawi Y, Wahyuniati N, Anwar S. Parent's hesitancy toward vaccination in indonesia: a cross-sectional study in Indonesia. Elsivier. Vaccine 38. 2020; 2592-99.

Triana V. Faktor yang berhubungan dengan pemberian imunisasi dasar lengkap pada bayi tahun 2015. JKMA. 2016; 10:123-135.

Azizi FSM, Kew Y, moy FM. Vaccine hesitancy among parents in a multi-ethnic country Malaysia. Elsivier. 2017;35:2955-61.

Opel DJ, Taylor JA, Zhou C. The relationship between parent attitudes about childhood vaccines survey scores and future child immunization status: a validation study. JAMA Pediatrics. 2013;167:1065-71

Esposito S, Principi N, Cornaglia G. Barriers to the vaccination of children and adolescents and possible solutions. Clin Microbial Infect. 2014;20:25-31 
Dube E, Vivion M, MacDonald NE. Vaccine hesitancy, vaccine refusal and the anti-vaccine movement: Influence, impact, and implications. Expert Rev Vacc. 2015;14(1).

Smith LE, Amlot R, Weinman J, Yiend J, Rubin GJ. A systematic review of factors affecting vaccine uptake in young children. Vaccine. 2017;35:6059-69

Sunaryo. Psikologi untuk keperawatan. EGC. Jakarta; 2004. h 98

Ajzen I. Attitudes, personality, and behaviour. Open University Press. New York

Isnayni E. Hubungan karakteristik ibu dan peran keluarga (inti dan non inti) dengan kelengkapan imunisasi dasar pada bayi; 2016 [diunduh 12 Juli 2020]. Tersedia pada www.repository.unair.ac.id

Noor NN. Epidemiologi. Rineka Cipta. Jakarta; 2008. h 46-9

Notoatmojo S. Promosi kesehatan dan ilmu perilaku. Rineka Cipta. Jakarta. 2012. h 70-2

Ningrum PE. Faktor-faktor yang mempengaruhi kelengkapan imunisasi dasar pada bayi di puskesmas bayudono kabupaten boyolali [skripsi]: Universitas Muhammadiyah Surabaya; 2008

Sewene MS, Rompas S, Lolong J. Analisis faktor-faktor yang berhubungan dengan kepatuhan ibu dalam pemberian imunisasi dasar di puskesmas tongkaina kecamatan bunaken kota madya manado. E-journal keperawatan. 2017;5:1-10

Riska H. Pengaruh karakteristik ibu terhadap ketidakpatuhan pemberian imunisasi dasar lengkap pada anak dibawah du tahun. Jurnal Berkala Epidemiologi. 2015;3:304-14

Kubli K, Sarah M, Hirsch J, Lorentz S. Student pharmacists' perceptions of imminizations;2017 [diunduh 2 Juli 2020]. Tersedia pada http://dx.doi.org/10.1016/j.cptl.2017.02.005.

Munib A. Pengantar ilmu pendidikan. Upt Unnes. Semarang; 2004.h 50-3 